\title{
Body Piercing
}

\section{Medical Concerns with Cutting-Edge Fashion}

Laura M. Koenig, MD, Molly Carnes, MD

\begin{abstract}
OBJECTIVE: To review the current information on medical complications, psychological implications, and legislative issues related to body piercing, a largely unregulated industry in the United States.
\end{abstract}

METHODS: We conducted a MEDLINE search of English language articles from 1966 until May 1998 using the search terms "body piercing" and "ear piercing." Bibliographies of these references were reviewed for additional citations. We also conducted an Internet search for "body piercing" on the World Wide Web.

MAIN RESULTS: In this manuscript, we review the available body piercing literature. We conclude that body piercing is an increasingly common practice in the United States, that this practice carries substantial risk of morbidity, and that most body piercing in the United States is being performed by unlicensed, unregulated individuals. Primary care physicians are seeing growing numbers of patients with body pierces. Practitioners must be able to recognize, treat, and counsel patients on body piercing complications and be alert to associated psychological conditions in patients who undergo body piercing.

KEY WORDS: body piercing; ear piercing; complications of body piercing.

J GEN INTERN MED 1999;14:379-385.

B ody piercing is becoming increasingly common in the United States. ${ }^{1-3}$ The practice of piercing a site other than the earlobe for jewelry display is becoming so accepted that a navel ring was worn by one of the contestants in the 1997 Miss America Pageant (Morgan D. Teen introduces body-piercing to Miss America Pageant. Reuters Limited. Sept. 10, 1997. Available from www.pathfinder.com/ iW4LUg...inment/latest/RB/1997Sep10/91.html). Along with the growing popularity of body piercing come risks of morbidity. Furthermore, most body piercing in the United

Received from the Department of Medicine, University of Wisconsin, Madison, Wis (LMK, MC).

Address correspondence to Dr. Koenig: University of Wisconsin Hospital and Clinics, 510 Monroe St., Fort Atkinson, WI 53538.

Address reprint requests to Dr. Carnes: Department of Medicine, University of Wisconsin Hospital and Clinics, 600 Highland Ave., Madison, WI 53792.
States is being performed by unlicensed, unregulated individuals. ${ }^{1-3}$

The piercing of various body sites has been practiced for thousands of years. Reasons for piercing have included adornment, rites of passage, religious purposes, and sexual practices. ${ }^{1-6}$ In Western society, piercing of the earlobe for adornment has become common. Piercing other sites of the body has been considered nontraditional until recent years. ${ }^{1,2,5}$

Health care professionals are faced with treating complications related to body piercing. This review examines the various body piercing complications and their treatment and discusses psychological, ethical, and legislative issues related to body piercing.

\section{METHODS}

This review includes a MEDLINE search using the search terms "body piercing" and "ear piercing” from 1966 until May 1998. Bibliographies of these references were reviewed for additional citations. "The Point" is a quarterly publication of the Association of Professional Piercers, ${ }^{3} \mathrm{a}$ self-regulatory organization for body piercing, which we found by an Internet search for body piercing sites on the World Wide Web. These publications were reviewed for additional information.

\section{Epidemiology}

Because of the intimate nature of many of the piercings, demographic data on body piercing are not easily obtained. ${ }^{5}$ Nine case reports of complications related to piercing sites other than the ear were found in the medical literature. ${ }^{7-15}$ These report substantial morbidity, including endocarditis from a nasal pierce ${ }^{7}$; sarcoid-like foreign body reaction from multiple body piercings ${ }^{8}$; paraphimosis from a pierce of the distal penis ${ }^{9}$; cellulitis of the submandibular, sublingual, and submental fascial spaces (Ludwig's angina) from a tongue pierce ${ }^{10}$; possible transmission of HIV type $1^{11}$; speech impairment from oral jewelry $^{12}$; swallowed jewelry ${ }^{13}$; a nipple pierce resulting in abscess of the left breast ${ }^{14}$; and urethral rupture from avulsion of a distal penile pierce. ${ }^{15}$

Methods of body piercing include use of springloaded guns with a disposable setup as well as autoclavable parts, or single-use piercing items such as needles 
and corks. ${ }^{4,5}$ Local anesthetic may be applied, but often is not. ${ }^{4,5}$ The jewelry is brought through the hole after the pierce. Jewelry gauge and size vary from very delicate for high ear piercings to large bore diameter for torso or genital piercings. ${ }^{2,4,5}$

\section{ANATOMIC SITES}

The traditional anatomic piercing site in Western society is the earlobe. Nontraditional body sites include a large number of oral/facial sites, nipple, navel, and genital piercings. ${ }^{1,2,4,5,15}$ Common oral/facial sites include high ear piercings involving the cartilage, piercing the ear tragus (see Fig. 1), nostril piercing, piercing of the septum of the nose, eyebrow piercing, piercing of the tongue (see Fig. 2), piercing of the lips, and piercing through the oral cavity to the skin in various sites. Common torso piercing sites include the nipple and navel areas. ${ }^{2,4,15}$ (See diagrams on nipple and navel pierces in Fig. 3A.)

Genital piercings often have specific names with historical significance. The Prince Albert is a pierce of the penis through the urethra and out behind the glans. This pierce was called a "dressing ring" by Victorian haberdashers. Its function was to secure the penis inside tightfitting men's trousers. The consort of Queen Victoria, Prince Albert, was believed to have had this pierce, leading to its current name. ${ }^{4}$ Other male genital piercings in-

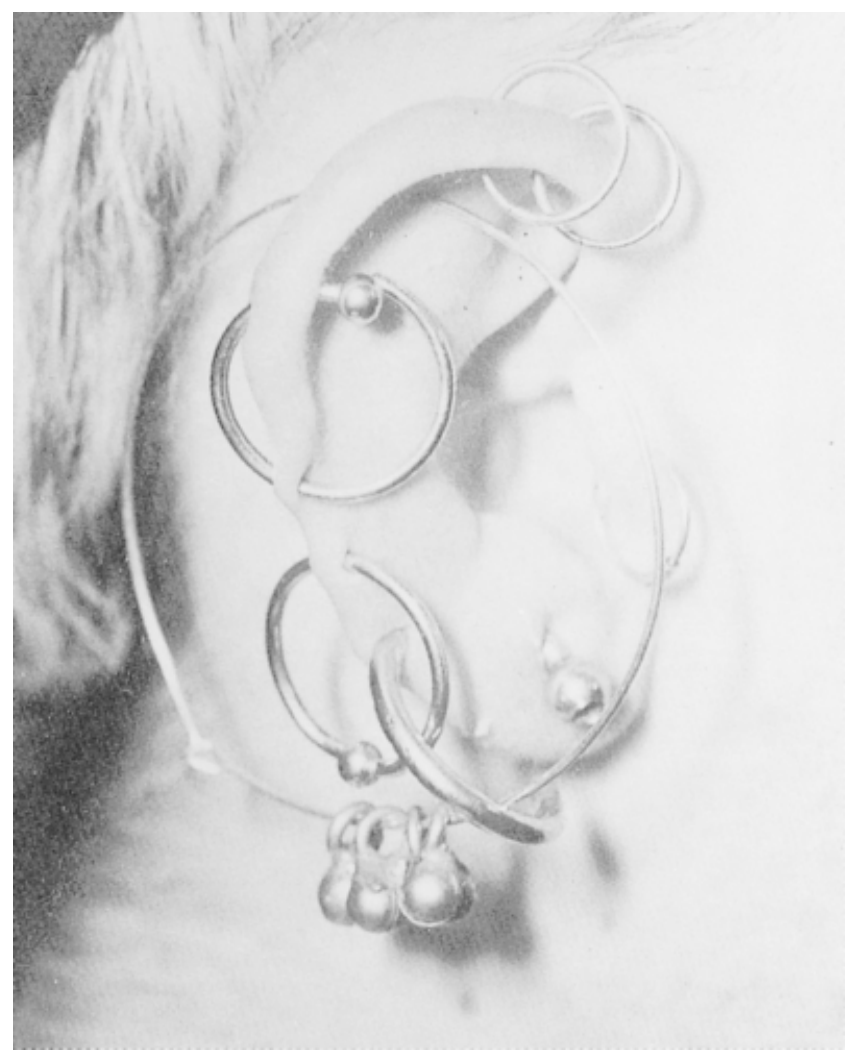

FIGURE 1. "High" ear pierces (reproduced from Juno and Vale4).

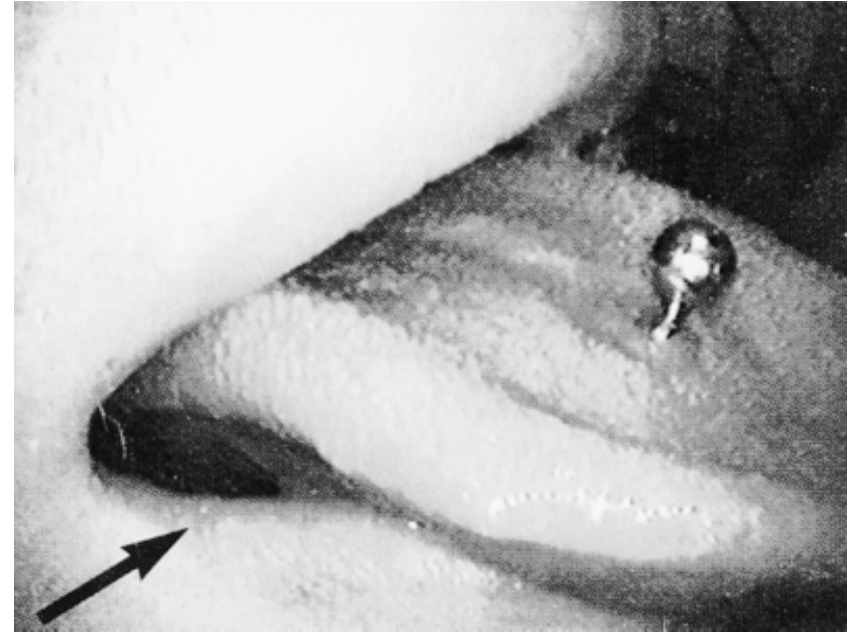

FIGURE 2. Tongue pierce, with arrow pointing to pierce on right lower lip (reproduced from Price and Lewis ${ }^{13}$ ).

clude the dydoe (lateral pierce of the glans often done in pairs), ampallang (horizontal pierce of the glans above the urethra), apadravya (vertical pierce of the glans, mentioned in the Kama-sutra), guiche (a perineal pierce between scrotum and anus that originated in the islands of the South Pacific), hafada (scrotal pierce that originated as an Arabian rite of passage), and frenum and foreskin pierces. $^{2,4}$ Female pierce sites include the clitoral hood and inner and outer labia. Perineal piercing in women and piercing the clitoris itself are uncommon. ${ }^{4}$ (For genital pierces, see diagrams in Figs. 3A and 3B.)

\section{COMPLICATIONS}

The complications associated with ear piercing have been estimated through surveys. Biggar and Haughie found the following complication frequencies in $497 \mathrm{fe}-$ male patients: redness and swelling (30\%), drainage (26\%), infection (24\%), bleeding (11\%), cyst formation (4\%), large scars (3\%), and trauma or tear $(2 \%) .{ }^{16}$ Cortese and Dickey surveyed 73 nursing students and found the following complication frequencies: allergic contact dermatitis (19\%), inflammation (15\%), bleeding (15\%), infection (15\%), nonpurulent drainage and crusting (12\%), cyst formation (3\%), and trauma (1\%). ${ }^{17}$ Similar complications are emerging from reports of nontraditional piercings.

\section{Infection}

A wide range of infections related to body piercing has been reported. ${ }^{5,6}$ Most of the data involve ear piercing. ${ }^{6}$ Bacterial infection can occur from improper initial piercing technique or from poor hygiene. ${ }^{6}$ Reports have been published of local soft tissue infection, ${ }^{5,6,18}$ perichondritis from high ear piercing, ${ }^{19-21}$ sepsis, ${ }^{22,23}$ and toxic shock syndrome. ${ }^{24}$ The susceptibility to infection is 
A

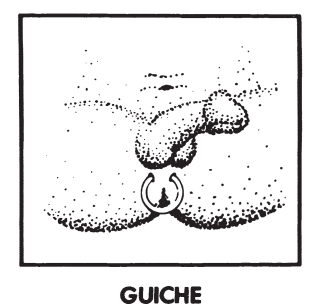

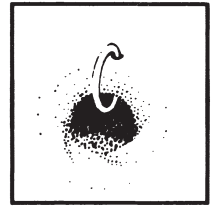

NAVE

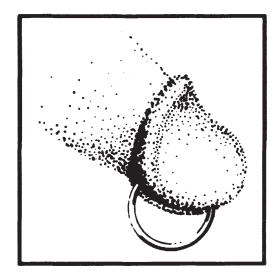

PRINCE ALBERT

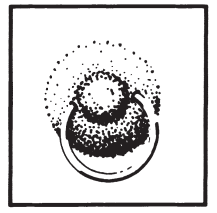

NIPPLE

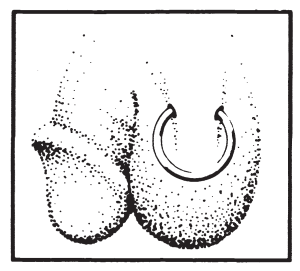

HAFADA

B

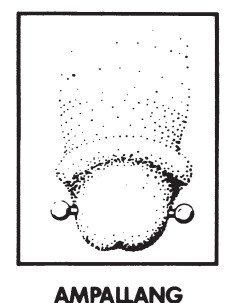

AMPALIANG

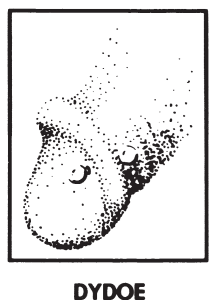

DYDOE

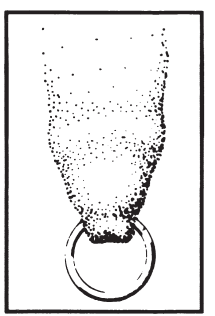

FORESKIN

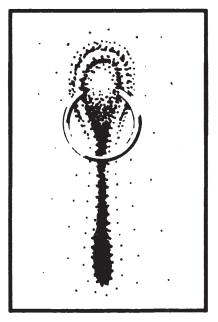

CLITORIS

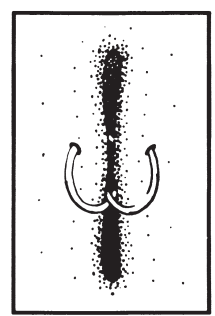

LABIA

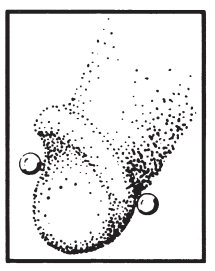

APADRAVYA

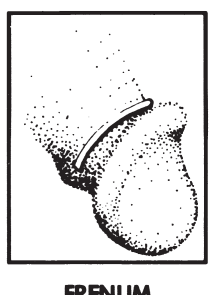

FRENUM

FIGURE 3. (A) Diagrams of nipple, navel, and genital pierces (reproduced from Juno and Vale ${ }^{4}$ ) and (B) diagrams of genital pierces (reproduced from Juno and Vale4).

increased by the presence of a foreign body. ${ }^{25,26}$ Persons with any immunocompromised state may be at increased risk of infection. ${ }^{6}$ Valvular heart disease or a preexisting lesion or anatomic deformity at the piercing site, such as psoriasis or dermatitis, also constitute risks of infection. ${ }^{6}$

The organisms involved in most piercing infections are skin pathogens such as streptococcal species and staphylococcal species. ${ }^{5,6}$ The perichondritis infections associated with high ear piercings have included more virulent organisms such as pseudomonal species.,19-21 The case reports of auricular infections with pseudomonal species include several that required intravenous antibiotics, placement of drainage tubes, and residual cartilaginous rim deformity after successful treatment. ${ }^{19-21} \mathrm{~A}$ case of staphylococcal endocarditis in a patient with no structural heart abnormality has been reported in association with a nasal pierce. ${ }^{7}$ The patient was treated successfully with a 6-week course of intravenous antibiotics including flucloxacillin and vancomycin. She had a minor degree of mitral incompetence after treatment, which was evident both clinically and echocardiographically. ${ }^{7}$

Another catastrophic case involved the development of cellulitis of the submandibular, sublingual, and submental fascial spaces (Ludwig's angina) after a tongue pierce, which required intubation and mechanical ventilation. ${ }^{10}$ The patient had not responded to oral therapy with amoxicillin given 4 days before admission to the hospital. Once hospitalized, the patient's airway was secured with endotracheal intubation, and she underwent surgical removal of the jewelry and surgical decompression of the floor of the mouth, with placement of three extra-oral drains. Antibiotic therapy with intravenous metronidazole, benzyl penicillin, and gentamicin was given. The patient required mechanical ventilation for 108 hours before she was successfully extubated. The patient recovered fully. ${ }^{10}$

A case of an abscess of the left breast developing after a nipple pierce has been reported. ${ }^{14}$ The patient responded to therapy with hot packs and oral ampicillin for 10 days. The ring had been removed prior to medical treatment. The patient recovered fully. ${ }^{14}$ One case of primary tuberculosis inoculated into the earlobe of a child by an infected adult has been reported. ${ }^{27}$ In 19th-century medical reports, deaths due to tetanus following piercing have been cited. ${ }^{28}$ Superficial lymphadenopathy has been reported in association with local inflammation or infection due to piercing as a temporary complication that typically resolves. ${ }^{6,29}$

Local infection can be managed with warm compresses, antibacterial soap, and topical antibacterial ointment. ${ }^{6}$ Much of the literature on infected puncture wound management comes from data obtained from animal bites. ${ }^{30}$ Closure of bite wounds, especially deep puncturetype wounds, is known to interfere with drainage. ${ }^{30}$ Similarly, if the body piercing site is one of a deeper puncture style, removal of the jewelry may allow closure of the wound without a channel for drainage. In this situation it is recommended the jewelry remain in place at the site of an apparent infection or be replaced with a sterile material or surgical drain. This would allow continued drainage from the infected area and prevent abscess formation. ${ }^{4}$ Systemic infection may require oral antibiotics or admission to the hospital for incision and drainage, or intravenous antibiotics. ${ }^{6,19-24}$

Viral hepatitis has been associated with piercing, ${ }^{6,31-34}$ particularly with the use of punch-style equipment with improper sterilization technique. ${ }^{6}$ Sharing nonsterilized 
earrings may increase the risk of transferring viral hepatitis. ${ }^{35}$ The newer vaccination recommendations for children in the United States for hepatitis B may decrease the risk of this disease; ${ }^{36}$ however, other blood-borne viral pathogens such as hepatitis $\mathrm{C}$ and HIV remain as major concerns. ${ }^{5,37}$ A case of possible transmission of HIV type 1 from body piercing has been reported. ${ }^{11}$ The patient underwent seroconversion to become HIV-1 positive after extensive body piercing. No other exposures during the period of seroconversion could be identified. He was asymptomatic at the time of the case report. ${ }^{11}$

Most piercing professionals supply care instructions that suggest cleaning products and dressing regimens to follow for a new pierce. ${ }^{4,5}$ Most piercing professionals also provide an estimated healing time for each pierce type. Many of the nontraditional piercing sites may take several months to heal fully. ${ }^{4,5}$

\section{Metal-Associated Complications}

Contact dermatitis from metal allergy associated with ear piercing has been widely reported. ${ }^{38-42}$ The condition usually presents as an eczematous rash. Nickel allergy has been the most common, ${ }^{6}$ and it can be so severe as to induce asthma. ${ }^{43,44}$ The metals that have led to nickel allergy have been nickel alloys or thin plating over nickel alloys. ${ }^{6}$ Contact sensitivity to gold, presenting as a lymphocytoma with a cutis-like lesion (benign lymphoplasia infiltrating the dermal layer), can occur in the earlobes and other areas pierced with gold jewelry. ${ }^{45-49}$ There also have been reports of a granulomatous response due to gold earrings, ${ }^{50}$ or a mixed lesion of both types. ${ }^{51}$ These lesions have responded to intralesional steroid treatment or surgical excision. ${ }^{46,47,49,50}$ Silver may also cause problems in body piercing. Localized argyria or silver poisoning has been reported. ${ }^{6,52-54}$ This lesion typically has been associated with embedded jewelry. ${ }^{52,53}$ The skin is believed to become discolored from the leeching of silver with formation of silver salts. ${ }^{6}$ This discolored area must be surgically excised. ${ }^{6}$

The metals being used in body piercing jewelry are usually surgical-grade stainless steel, solid $14 \mathrm{~K}$ or $18 \mathrm{~K}$ gold, or other choices such as niobium titanium, and platinum. ${ }^{3-5}$ Patch testing can identify metal-sensitized individuals. ${ }^{6,55}$ The dimethylglyoxime test has been utilized in dermatology offices and jewelry stores to identify jewelry with nickel as a component. ${ }^{6,56}$ This method uses a $1 \%$ solution of dimethylglyoxime in alcohol and a $10 \%$ solution of ammonium hydroxide in water. Two drops of each solution are placed on a cotton swab. The swab is rubbed against any test item suspected of containing nickel, for 30 seconds. The appearance of a red color, from light pink to strong cerise, indicates that the release of nickel exceeds $0.5 \mu \mathrm{g} / \mathrm{cm}^{2}$ per week. ${ }^{56}$ Avoiding the material causing the reaction, with use of topical or intralesional corticosteroids if necesary, will usually lead to resolution. ${ }^{6}$

\section{Hypertrophic Scars and Keloids}

Hypertrophic scars and keloid formation are also reported as complications of piercing. Much of the literature deals with the treatment and surgical excision of these lesions in association with ear piercing. ${ }^{6,57-60}$ Keloids have a higher incidence in blacks and Asians. ${ }^{6}$ There has been a recent noted rise in incidence of keloids in men as they increasingly undergo piercing. ${ }^{61}$ Treatment includes intralesional corticosteroids, pressure, and surgical excision. ${ }^{57-60}$ Intralesional verapamil in conjunction with the other modalities appears promising. ${ }^{62}$

\section{Other Complications}

Trauma to a pierce site is another complication associated with piercing. Edema and hematoma may occur from the trauma of the initial piercing, or at the site of trauma to an established pierce. ${ }^{6}$ Cold compresses, pressure, and removal of jewelry usually resolve this problem. ${ }^{6}$ Improper jewelry may irritate and injure adjacent tissue. ${ }^{4,6}$ Heavy jewelry or accidental pulling may lead to torn tissue, which may require surgical repair.6,63,64 A case of urethral rupture following avulsion of a Prince Albert penile ring has been reported. ${ }^{15}$ The wound created by the avulsion was a ventral split of the urethra. The patient was managed conservatively, and the urethra healed without surgical intervention. ${ }^{15}$ Management of urethral tears typically involves evaluation by retrograde urethrography. ${ }^{65} \mathrm{~A}$ partial tear may be converted to a complete transection by the inadvertent introduction of a catheter. Partial tears may require a suprapubic cystotomy and primary repair. ${ }^{65}$

Embedded jewelry is another complication reported with piercing. ${ }^{6,66-72}$ Typically this has been associated with the use of an ear-piercing gun. ${ }^{70,71}$ The earring back may become embedded in the earlobe if the jewelry setup is placed too tightly under high pressure. Rotating the new jewelry to change pressure points may help avert this problem. ${ }^{6,70,71}$ The treatment is excision under local anesthesia. $^{6}$

There are case reports of sarcoidal-like granuloma formation at a pierce site in patients without clinical sarcoidosis. ${ }^{8,50,73}$ Most, but not all of the cases in these reports had an association with gold jewelry. ${ }^{49,73}$ One patient had a positive Kviem test. ${ }^{73}$ Sarcoidal tissue reaction from a ritual involving body piercing with multiple skin hooks and skewers made of an unknown metal was reported. ${ }^{8}$ Two patients in this report were identified with masses in the buccal mucosa consistent with sarcoid-like lesions by histopathology. The lesions developed at the site of previous piercings. One patient responded to intralesional injections of triamcinolone acetonide in tandem with oral prednisone. No information was available on the mode of treatment for the other case. ${ }^{8}$ Treatment of sarcoidal-like lesions with intralesional corticosteroids, systemic corticosteroids, or surgical excision has been successful. ${ }^{8,50}$ 
Epidermal cyst formation has been reported and is believed to be from the penetration of epidermal cells into the dermis during the piercing process. ${ }^{6}$ Treatment is excision with a skin punch. ${ }^{6}$ Finally, contact dermatitis from cleaning products, antibacterial ointment (especially neomycin-containing ointment), or primary irritant contact dermatitis have also been reported. ${ }^{6}$

Nontraditional piercings have been associated with site-specific complications. Only a few site-specific complications have been reported thus far. The possible sitespecific complications of oral/facial piercings include aspiration of jewelry with airway obstruction, chipped or cracked teeth, prolonged bleeding from piercings of areas of high vascularity, cellulitis of the submandibular, sublingual, and submental fascial spaces (Ludwig's angina), the treatment for which is described above, as well as gingival injury, interference with mastication and swallowing, speech impediment, increased salivary flow, and obstruction of radiographs as in the odontoid view on a cervical-spine series in the evaluation of trauma. ${ }^{10,12,13}$

A case of a swallowed uvula ornament was reported, with no adverse outcome. ${ }^{13}$ A case of a tongue pierce causing a slight lisp has been reported, with the patient tolerating the effect. ${ }^{12}$ A genital pierce caused a case of paraphimosis, which required manual reduction after a penile block. ${ }^{9}$ The treatment of paraphimosis is typically manual reduction. ${ }^{9}$ Other methods of treatment include the puncture technique, injection of hyaluronidase, and application of a topical hypertonic solution, or if the glans is particularly tight, a dorsal slit may be required. ${ }^{9}$ Piercing of cartilage may lead to perichondritis, which can be treated as described previously. ${ }^{19-21}$

Migration and rejection of piercing jewelry can occur. $^{2,4}$ The jewelry chosen must be of a sufficient diameter for the site to heal properly without expulsion of the jewelry from the pierced tissue. ${ }^{2,4}$ Piercings of the body in flat surface areas such as the chest wall will almost always migrate and be rejected. ${ }^{4}$

The implications of navel, nipple, and genital piercings in women who are, or plan to become, pregnant are undefined at this time in terms of complications associated with body changes, delivery, and nursing. Also undefined is the likelihood of increased risk of mucosal trauma with unprotected sexual activity, or condom tear with sexual activity if genital jewelry is not removed. This may lead to an increased risk of sexually transmitted disease or pregnancy.

\section{PSYCHOLOGICAL IMPLICATIONS}

Body piercing is emerging as a form of body art, with certain nontraditional pierces becoming well accepted in Western society. ${ }^{1-3}$ Some piercing sites signify an expression of ethnic heritage, while other piercing is undertaken for sexual practices. ${ }^{1-5}$ Piercing has also been posed as a variant of self-mutilation, ${ }^{4,74,75}$ along with other increasingly popular forms of body modification such as decorative scarification, tattooing, and branding. ${ }^{4,75}$ Some indi- viduals who have suffered some form of physical or sexual abuse in the past have expressed a sense of empowerment after obtaining a pierce, cut, tattoo, or brand in a nonviolent environment. The act of self-mutilation has been described as a means of reducing tension via a relaxation response that occurs after the event. ${ }^{76}$ It is unclear at this time if the motivation of some piercing enthusiasts is other than simple body modification.

\section{LEGAL AND ETHICAL ISSUES}

Although tattooing, ear piercing, electrolysis, and acupuncture are regulated by local bylaws in most areas in the United States, the activity of nontraditional body piercing is licensed and regulated in only a few states and municipalities. ${ }^{1-3,5}$ The Association of Professional Piercers (APP) formed in an attempt to initiate self-regulatory policies along the same lines as the Alliance of Professional Tattooists (APT). ${ }^{3,36}$ Most individuals performing body piercing are self-trained. ${ }^{3,4} \mathrm{~A}$ handful of states are in the process of enacting legislation to regulate body piercing. ${ }^{3}$

Another issue is that of informed consent prior to obtaining a body pierce. A survey evaluating the adequacy of informed consent for ear piercing indicated that questions regarding previous piercings and complications such as keloids were usually not asked before piercing. ${ }^{77}$ Because keloids are a potentially disfiguring complication of a procedure procured for adornment, the authors of the survey felt it should be included in standard piercing consent. ${ }^{77}$ At this point in time, no standards exist for obtaining informed consent for body piercing.

\section{CONCLUSIONS}

This review of body piercing found that many of the complications of nontraditional pierces are similar to those previously reported for earlobe piercing. New complications, however, many of which are site specific, are increasingly being seen in the medical setting. The presence of a foreign body increases susceptibility to infection, and nontraditional sites, once infected, may have more complications because the punctures are deeper or involve avascular tissue such as cartilage. Health care professionals need to be able to recognize and treat complications related to body piercing and identify variants of selfmutilation. The health and safety risks of body piercing indicate that standardized legislation and regulation is needed for practitioners who perform this service.

The authors thank Julia McMurray, MD, Associate Professor of Medicine, University of Wisconsin Hospital and Clinics, for manuscript review. This work was supported in part by National Institutes of Health grant K07AG00744.

Figures $1,3 A$, and $3 B$ were reproduced with permission from RE/Search Publications, San Francisco, Calif. Figure 2 was reproduced with permission of ADA Publishing Co., Inc., Chicago, III. Copyright (C) 1977, American Dental Association. 


\section{REFERENCES}

1. Wright JW. Modifying the body: piercing and tattoos. Nurs Stand. 1995;10(11):27-30.

2. Muldoon KA. Body piercing in adolescents. J Pediatr Health Care. 1997;11:298-301.

3. Association of Professional Piercers. The Point. 1998; issues 1-6, 11. Available from www.safepiercing.org/point.

4. Juno A, Vale V, eds. Research No. 12: Modern Primitives: An Investigation of Contemporary Adornment and Ritual. San Francisco, Calif. RE/Search Publications; 1989.

5. Tweeten SSM, Rickman LS. Infectious complications of body piercing. Clin Infect Dis. 1998;26:735-40.

6. Hendricks WM. Complications of ear piercing: treatment and prevention. Cutis. 1991;48:386-94.

7. Ramage IJ, Wilson N, Thomson RB. Fashion victim: infective endocarditis after nasal piercing. Arch Dis Child. 1997;77(2):187. Letter.

8. Han K, Siar CH, Ganesapillai T, Lumpur K. Sarcoid-like foreign body reaction in body piercing-a report of two cases. Oral Surg Oral Med Oral Pathol Oral Radiol Endod. 1997;84(1):28-31.

9. Jones SA, Flynn RJ. An unusual (and somewhat piercing) cause of paraphimosis. Br J Urol. 1996;78(5):803-4.

10. Perkins CS, Meisner J, Harrison JM. A complication of tongue piercing. Br Dent J. 1997;182(4):147-8.

11. Pugatch D, Mileno M, Rich JD. Possible transmission of human immunodeficiency virus type 1 from body piercing. Clin Infect Dis. 1998;26: 767-8.

12. Chen M, Scully C. Tongue piercing: a new fad in body art. Br Dent J. 1992;172:87. Letter.

13. Price SS, Lewis MW. Body piercing involving oral sites. J Am Dent Assoc. 1997;128(7):1017-20.

14. Fiumara MJ, Capek M. The Brustwarze, or nipple ring. Sex Transm Dis. 1982;9:138-9.

15. Higgins SP, Estcourt CS, Bhattacharvya MN. Urethral rupture in a homosexual male following avulsion of a Prince Albert penile ring. Int J STD AIDS. 1995;6:54-5.

16. Biggar RJ, Haughie GE. Medical problems of ear piercing. NY State J Med. 1975;75:1460-2.

17. Cortese TA, Dickey RA. Complications of ear piercing. Am Fam Physician. 1971;4:66-72.

18. George J, White M. Infection as a consequence of ear piercing. Practitioner. 1989;233:404-6.

19. Widick MH, Coleman J. Perichondral abscess resulting from a high ear-piercing. Otolaryngol Head Neck Surg. 1992;107:803-4.

20. Cossette JE. High ear-piercing. Otolaryngol Head Neck Surg. 1993;109(5):967-8. Letter.

21. Staley R, Fitzgibbon JJ, Anderson C. Auricular infections caused by high ear piercing in adolescents. Pediatrics. 1997;182(4):147-8.

22. Lovejoy FH Jr, Smith DH. Life-threatening staphylococcal disease following ear piercing. Pediatrics. 1970;46:301-3.

23. Shulman BH. Ear piercing and sepsis. Clin Pediatr. 1973;12:27A.

24. McCarthy VP, Peoples WM. Toxic shock syndrome after ear piercing. Pediatr Infect Dis J. 1988;7(10):741-2.

25. Jansen B, Peters G. Foreign body associated infection. J Antimicrob Chemother. 1993;32 (suppl A):69-75.

26. Zimmerli W, Waldvogel FA, Vaudaux P, Nydegger UE. Pathogenesis of foreign body infection: description and characteristics of an animal model. J Infect Dis. 1982;146:487-96.

27. Morgan LG. Primary tuberculosis inoculation of an ear lobe. J Pediatr. 1952;40:482-5.

28. Thorner M. Pathological conditions following piercing of the lobules of the ear. JAMA. 1894;22:110-2.

29. Ashkenazi S, Mimouni M, Varsano I, Feingold M. Superficial cervical lymphadenopathy after insertion of earrings. Am J Dis Child. 1984; 138: 1147-8.

30. Lewis TL, Stiles M. Management of cat and dog bites. Am Fam Physician. 1995;52(2):479-85.
31. Castelman B, McNeely BU. Case records of the Massachusetts General Hospital. N Engl J Med. 1966;274:1317-25.

32. Massachusetts Department of Health. Another hole in the head. N Engl J Med. 1974;291:99-100.

33. Johnson CJ, Anderson H, Spear H. Ear piercing and hepatitis: nonsterile instruments for ear piercing and the subsequent onset of viral hepatitis. JAMA. 1974;227(10): 1165.

34. Mele A, Corona R, Tosti ME, et al. Beauty treatments and risk of parenterally transmitted hepatitis: results from the Hepatitis Surveillance System in Italy. Scand J Infect Dis. 1995;27(5):441-4.

35. Walson PD, Brady MT. Earrings: a source of bloodborne infections? Pediatrics. 1992;90(6):1005. Letter.

36. Merck. Visions in Vaccinations: Tattooing and Piercing . . . What Your Patients Need to Know. New York, NY: Merck \& Co; 1997.

37. MacLennan S, Moore MC, Hewitt PE, Nicholas S, Barbar JAJ. A study of anti-hepatitis C positive blood donors: the first year of screening. Transfus Med. 1994;4:125-33.

38. Gaul LE. Development of allergic nickel dermatitis from earrings. JAMA. 1967;200(2):186-8.

39. Fischer T, Fregert S, Gruvberger B, Rystedt I. Nickel release from ear piercing kits and earrings. Contact Dermatitis. 1984;10:39-41.

40. Larsson-Stymne B, Widstrom L. Ear piercing-a cause of nickel allergy in schoolgirls? Contact Dermatitis. 1985;13:289-93.

41. Nakada T, Iijima M, Nakayama H, Maibach HI. Role of ear piercing in metal allergic contact dermatitis. Contact Dermatitis. 1997;36: 233-6.

42. Fisher AA. Allergic dermal contact dermatitis due to gold earrings. Cutis. 1987;39(6):473-5. Letter.

43. Block GT, Yeung MB. Asthma induced by nickel. JAMA. 1982; 247(11):1600-2.

44. Fisher JR, Rosenblum GA, Thomson BD. Asthma induced by nickel. JAMA. 1982;248(9):1065-6. Letter.

45. Shelley WB, Epstein E. Contact-sensitivity to gold as a chronic papular eruption. Arch Dermatol. 1963;87:388-91

46. Hoossik P, Macmillan AL. Allergic contact sensitivity to gold with unusual features. Br J Dermatol. 1973;88:505-8.

47. Iwatsuki K, Tagami H, Moriguchi T, Yamada M. Lymphadenoid structure induced by gold hypersensitivity. Arch Dermatol. 1982; 118:608-11.

48. Iwatsuki K, Yamada M, Takigawa M, Inoue K, Matsumoto K. Benign lymphoplasia of the earlobes induced by gold earrings: immunohistologic study on the cellular infiltrates. J Am Acad Dermatol. 1987;16:83-8.

49. Kobayashi Y, Nanko H, Nakamura J, Mizoguchi M. Lymphocytoma cutis induced by gold pierced earrings. J Am Acad Dermatol. 1992;27(3):457-8.

50. Armstrong DKB, Walsh MY, Dawson JF. Granulomatous contact dermatitis due to gold earrings. Br J Dermatol. 1997;136(5):776-8.

51. Aoshima T, Oguchi M. Intracytoplasmic crystalline inclusions in dermal infiltrating cells of granulomatous contact dermatitis due to gold earrings. Acta Derm Venereol. 1988;68(3):261-4.

52. van den Nieuwenhuijsen IJ, Calame JJ, Bruynzeel I. Localized argyria caused by silver earrings. Dermatologica. 1988;177(3):189-91.

53. Shall L, Stevens A, Millard LG. An unusual case of acquired localized argyria. Br J Dermatol. 1990;123:403-7.

54. Morton CA, Fallowfield M, Kemmett D. Localized argyria caused by silver earrings. Br J Dermatol. 1996;135(3):484-5.

55. Emmett EA, Risby TH, Jiang L, Ng SK, Feinman S. Allergic contact dermatitis to nickel: bioavailability from consumer products and provocation threshold. J Am Acad Dermatol. 1988;19:314-22.

56. Fisher AA. Denmark: the dimethylglyoxime test and international nickel dermatitis. Cutis. 1990;46:386-7.

57. Weimar VM, Ceilley RI. Treatment of keloids on earlobes. J Dermatol Surg Oncol. 1979;5(7):522-3.

58. Salasche SJ, Grabski WJ. Keloids of the earlobes: a surgical technique. J Dermatol Surg Oncol. 1983;9(7):552-6.

59. Pollack S, Goslen JB. The surgical treatment of keloids. J Dermatol Surg Oncol. 1982;8(12):1045-9. 
60. Rauscher GE, Kolmer WL. Treatment of recurrent earlobe keloids. Cutis. 1988;37:67-8.

61. Ofodile FA. Men, earrings, and keloids. Plast Reconstr Surg. 1995;96:495-6. Letter.

62. Thomas-Lawrence WT. Treatment of earlobe keloids with surgery plus adjuvant intralesional verapamil and pressure earrings. Ann Plast Surg. 1996;37(2):167-9.

63. Casson P. How do you repair a split earlobe? J Dermatol Surg. 1976;2(1):21.

64. Effendi SH. Reconstruction of the middle-aged torn earlobe: a new method. Br J Plast Surg. 1988;41:174-6.

65. Cortellini P, Ferretti S, Larosa M, Peracchia G, Arena F. Traumatic injury of the penis: surgical management. Scand J Urol Nephrol. 1996;30:517-9.

66. Jay AL. Ear-piercing problems. BMJ. 1977;2:574-5. Letter.

67. Cockin J, Finan P, Powell M. A problem with ear piercing. BMJ. 1977;2:1631.

68. Gibson OB. A problem with ear piercing. BMJ. 1978;1:178. Letter.

69. Salleeby ER, Rubin MG, Youshock E, Kleinsmith DM. Embedded foreign bodies presenting as earlobe keloids. J Dermatol Surg Oncol. 1984;10(11):902-4.

70. De San Lazaro C, Jackson RH. Vanishing earrings. Arch Dis Child. 1986;61:606-7.

71. Muntz HR, Cui DJ, Asher BF. Embedded earrings: a complication of the ear-piercing gun. Int J Pediatr Otorhinolaryngol. 1990;19(1):73-6.

72. Cohen HA, Nussinovitch M, Straussberg R. Embedded earrings. Cutis. 1994;53(2):82.

73. Mann RJ, Peachey RDG. Sarcoidal tissue reaction-another complication of ear-piercing. Clin Exp Dermatol. 1983;8:199-200.

74. Ali AH. Borderline personality and multiple earrings: a possible correlation? Am J Psychiatry. 1990;147(9):1251. Letter.

75. Farber SK. Self-medication, traumatic reenactment, and somatic expression in bulimic and self-mutilating behavior. Clin Soc Work J. 1997;25(1):87-106.

76. Haines J, Williams CL. Coping and problem solving of self-mutilators. J Clin Psychol. 1997;53(2):177-86.

77. Gaughf CN, Pritzker AS, Davis L. Survey of informed consent for ear piercing: risk of keloids. Pediatr Dermatol. 1996;13(5):430.

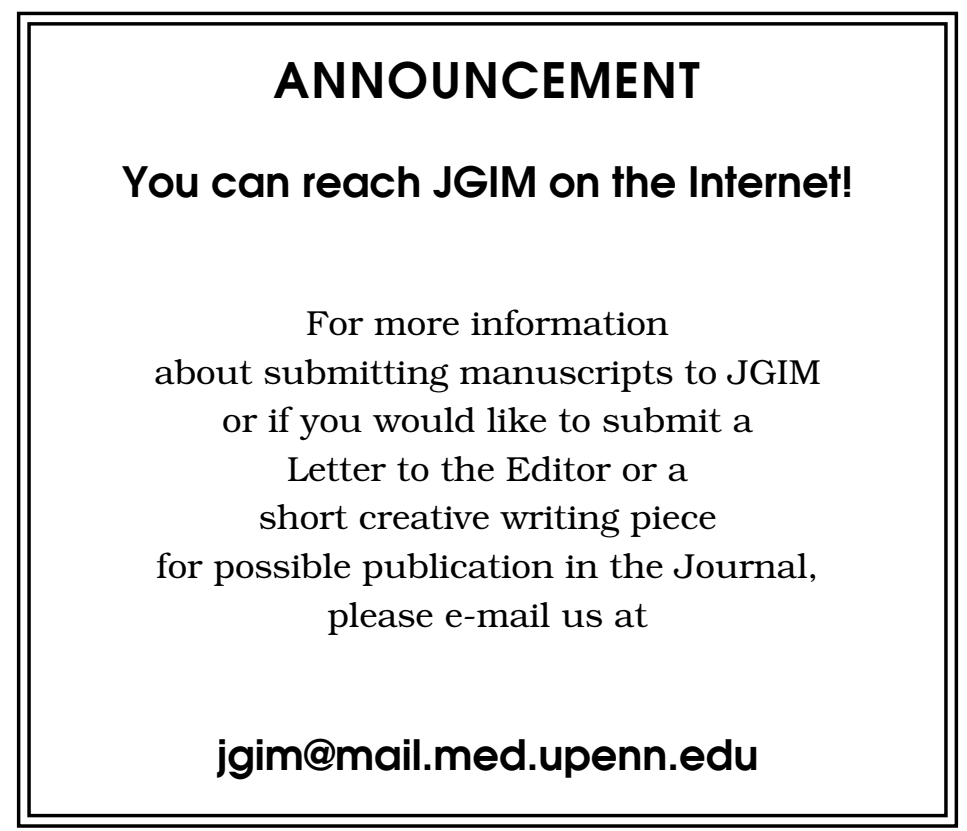

